International Journal of Current Advanced Research

ISSN: O: 2319-6475, ISSN: P: 2319 - 6505, Impact Factor: SJIF: 5.995

Available Online at www.journalijcar.org

Volume 6; Issue 4; April 2017; Page No. 3206-3208

DOI: http://dx.doi.org/10.24327/ijcar.2017.3208.0226

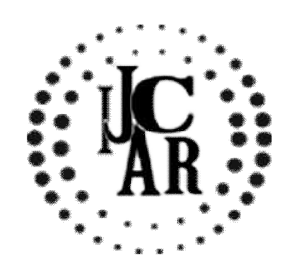

Research Article

\title{
TEENAGE PREGNANCY OUTCOMES IN TEACHING HOSPITALS IN YAOUNDÉ
}

\section{Tebeu PM1., Belinga E*1., Halle Ekane G-E²., Mossiang Kadje $L^{1}$., Ekono MR ${ }^{3}$ and Mbu Enow $\mathbf{R}^{1}$}

\author{
${ }^{1}$ Department of Obstetrics and gynaecology, Faculty of Medicine and Biomedical Sciences,
} The University of Yaounde I, Cameroon

2Department of Obstetrics and gynaecology, Faculty of Health Sciences, University of Buea, Cameroon

${ }^{3}$ Faculty of Medicine and Pharmaceutic Sciences, University of Douala, Cameroon

\section{A R T I C L E I N F O}

\section{Article History:}

Received $17^{\text {th }}$ January, 2017

Received in revised form $9^{\text {th }}$ February, 2017

Accepted $22^{\text {nd }}$ March, 2017

Published online $28^{\text {th }}$ April, 2017

\section{Key words:}

Teenagers, pregnancy, childbirth, outcomes, Cameroon.

\begin{abstract}
A B S T R A C T
Teenage pregnancies are high risk of maternal and perinatal complications. The objective was to analyze the outcomes of teenage pregnancies in primiparous. It was an analytical cross-sectional study from September 2012 to April 2013, in maternity wards of the University Hospital and the Central Hospital of Yaoundé. Sixty primiparous adolescents aged 14 to 19 years were compared to 100 primiparous aged 20 to 24 years who gave birth in the study sites. The demographic profile, prenatal care, labor, childbirth and newborns in birth rooms were analyzed. Data was expressed as frequencies and percentages and was analyzed by Chi square test or Fisher's exact test where appropriate for significance. Odds Ratio for association was calculated. $\mathrm{P}$ was significant when $<0.05$. Compared to adults, few teenagers: reached the university level $(\mathrm{P}<0.001)$ and took preventive treatment of malaria $(\mathrm{p}=0.041)$. The adolescents had more fever during labor $(\mathrm{p}=0.009)$ and their newborns had a low Apgar score $(<7)$ in the first minute $(\mathrm{p}=0.014)$. Poor prenatal care, fever during labor and a low Apgar score affect significantly teenage pregnancies.
\end{abstract}

Copyright $\mathrm{C} 2017$ Belinga $\boldsymbol{E}$ et al. This is an open access article distributed under the Creative Commons Attribution License, which permits unrestricted use, distribution, and reproduction in any medium, provided the original work is properly cited.

\section{INTRODUCTION}

According to the World Health Organization, about 16 million girls aged 15 to 19 years and 1 million girls aged under 15 years give birth each year representing $11 \%$ of global births, 95\% occurring in low- and middle-income countries (Chandra-Mouli V, 2013). In teenagers, complications of pregnancy and childbirth are the second leading cause of death. New-borns of teenage mothers have a higher risk of low birth weight and a higher perinatal death $50 \%$ than those of mothers of 20 to 29 years old (ChandraMouli V, 2013).

In Cameroon, previous studies have shown that pregnancies in teenagers are high risk of preterm birth, fetal distress, use of oxytocin during labor, perineal tears and episiotomy (Tebeu PM, 2011). They also have a high risk of caesarean delivery and stillbirth (Nkwabong E, 2009). Transmission of HIV virus also increases with high rates of episiotomy and perineal tears (Nkwabong E, 2009). Furthermore, the risk of fetal growth retardation is high (Tebeu PM, 2011). However, teenagers still contribute for 9.3 to $14.23 \%$ of deliveries in Cameroun (Fouelifack FY, 2014) (Egbe TO, 2015) (Enquête Démographique et de Santé et à Indicateurs Multiples(EDSMICS), 2011).This study was carried out to analyze mother and child outcomes in teenage pregnancies.

\section{*Corresponding author: Belinga $\mathbf{E}$}

Department of Obstetrics and gynaecology, Faculty of

Medicine and Biomedical Sciences,

The University of Yaounde I, Cameroon

\section{Objective}

To analyze maternal and neonatal outcomes in teenage pregnancies in order to improve on their management in Cameroon.

\section{MATERIALS AND METHODS}

It was a cross-sectional analytic study from September 2012 to April 2013 in two maternities: The Yaoundé University Teaching Hospital and the Yaoundé Central Hospital. A group of pregnant teenagers in first delivery, aged 14 to 19 years was compared to a group of primiparous young adults aged 20 to 24 years who gave birth in the two maternities during the study period. All those who met our inclusion criteria and gave their consent were involved. Were included consecutively teenagers and young adults in labor with singleton pregnancy at gestational age higher or equal to 28 weeks.A pre-tested questionnaire was used to collect data from delivery rooms registers and patient files. Data was collected on the following variables: sociodemographic characteristics, parity, quality of antenatal visits (number, site, quality of staff, prophylaxis), the number of obstetric ultrasound, pregnancy gestational age, the onset of labor, partogram features, type of delivery, Apgar score at first and fifth minute, foetal death and maternal death. The sample size calculation was based on a $30 \%$ prevalence of premature delivery among teenagers (Tebeu PM, 2011). Data were analysed using Epi-Info version 7. Data was expressed as 
frequencies and percentages and analysed by Chi square test or Fischer's exact Test where appropriate. Odds Ratio and $95 \%$ confidence interval for association was calculated. A pvalue of $<0.05$ was considered statistically significant.

\section{RESULTS}

Concerning socio-demographic characteristics, fewer teenage mothers: had reached the university level of education $(17 \%$ vs $68 \%$; P $<0.001)$; were married (26\% vs $54 \%$; p $<0.001)$ and stayed at husband houses compared to adults $(26.7 \%$ vs $54 \% ; \mathrm{p}<0.001)$. Teenage mothers were more likely to be employed compared to adult mothers $(80 \%$ vs $59 \%$; $\mathrm{P}<$ 0.006) (Table I).

Table I Significant Sociodemographic Characteristics

\begin{tabular}{|c|c|c|c|c|}
\hline \multirow[b]{2}{*}{ Variables } & \multicolumn{2}{|c|}{ Maternal age group } & \multirow{2}{*}{$\begin{array}{l}\text { Total } \\
\text { n(\%) }\end{array}$} & \multirow[b]{2}{*}{ P value } \\
\hline & $\begin{array}{c}\text { 14-19 years } \\
\text { n(\%) }\end{array}$ & $\begin{array}{c}\text { 20-24 years } \\
\text { n(\%) }\end{array}$ & & \\
\hline Average age (SD) & $18.15(1.06)$ & $22.64(1.25)$ & $\begin{array}{l}20.96 \\
(2.48)\end{array}$ & $<0.001$ \\
\hline Level of education & & & & $<0.001$ \\
\hline Primary & $11(18)$ & $5(16)$ & $16(10)$ & \\
\hline Secondary & $39(65)$ & $26(26)$ & $65(40)$ & \\
\hline University & $10(17)$ & $68(68)$ & $78(48.8)$ & \\
\hline Living conditions & & & & $<0.001$ \\
\hline Alone & $1(1.7)$ & $11(11)$ & $12(7.5)$ & \\
\hline WithUncle / Aunt & $2(3.3)$ & $0(0.0)$ & $2(1.3)$ & \\
\hline With a brother / sister & $39(65)$ & $26(26)$ & $76(40)$ & \\
\hline With parents & $9(15)$ & $14(14)$ & $23(14.3)$ & \\
\hline Withboth parents & $25(41.7)$ & 19(19) & $44(27.5)$ & \\
\hline Withpartner / husband & $16(26.7)$ & $54(54)$ & $70(43)$ & \\
\hline Parental occupation & & & & \\
\hline Unemployed & $12(20)$ & $41(41)$ & $53(63)$ & 0.006 \\
\hline Employee & $48(80)$ & $59(59)$ & $107(66.9)$ & \\
\hline
\end{tabular}

With regard to antenatal visits, adults' mothers were approximately 3 times more likely to have had previous pregnancies compared to teenage mothers $(73.3 \%$ vs $49.0 \%)$ (OR, 2.81; 95\% CI, $1.50-5.31: \mathrm{p}=0.003$ ) and were 2.34 times more likely to have taken Intermittent Preventive Treatment against malaria compared to teenage mothers $(82.8 \%$ vs $64.0 \%)$; (OR, 2.34; 95\% CI, 1.27-4.54: $\mathrm{p}=$ 0.041). Both groups were similar with regard to the number and site of antenatal visits, quality of staff attended and number of ultrasonography examinations done (Table II).

Table II Significant Features of Prenatal Care

\begin{tabular}{|c|c|c|c|c|c|}
\hline \multirow[b]{2}{*}{ Variables } & \multicolumn{2}{|c|}{ Maternal age group } & \multirow[b]{2}{*}{$\begin{array}{l}\text { Total } \\
\text { n(\%) }\end{array}$} & \multirow[b]{2}{*}{$\begin{array}{c}\text { OR } \\
(95 \% C I)\end{array}$} & \multirow[b]{2}{*}{$\begin{array}{c}\mathbf{P} \\
\text { value }\end{array}$} \\
\hline & $\begin{array}{l}14-19 \\
\text { years } \\
n(\%)\end{array}$ & $\begin{array}{l}20-24 \\
\text { years } \\
\text { n(\%) }\end{array}$ & & & \\
\hline \multicolumn{6}{|c|}{ Previous pregnancies } \\
\hline 1 & $44(73.3)$ & $49(49)$ & $93(58.1)$ & $2.81(1.5-5.31)$ & 0.003 \\
\hline 2 à 4 & $16(26.7)$ & $51(51)$ & $67(41.9)$ & & \\
\hline \multicolumn{6}{|l|}{ *IPT } \\
\hline 0 dose & $3(6)$ & $3(3.2)$ & $6(4.2)$ & $2.34(1.27-4.54)$ & 0.041 \\
\hline 1 dose & $15(30.0)$ & $13(14.0)$ & $28(19.6)$ & & \\
\hline 2-3 doses & $32(64)$ & $77(82.8)$ & $109(76.2)$ & & \\
\hline
\end{tabular}

*IPT: Intermittent preventive treatment of malaria

Data on labor, delivery and neonatal status did not show a significant difference in both groups on gestational age at delivery, onset of labor and duration of labor. On contrary, teenage mothers had five-fold more fever during labor than their counterparts attributed to malaria $(16.7 \%$ vs $4.0 \%)$, (OR, 4.92; 95\% CI, 1.51-8.73: $\mathrm{p}=0.009)$. Poor Apgar score below 7 in the first minute was more frequent among newborns from teenage mothers than in the newborns from the adult mothers (OR, 2.07; 95\% CI, 1.29-3.34: $\mathrm{p}=0.014)$, but the difference was not significant in the fifth minute. Fetal death was $5.0 \%$ among teenage deliveries and $2.0 \%$ among adult deliveries without significant difference. No maternal death occurred (Table III).

Table III Significant Characteristics of Labor and Childbirth

\begin{tabular}{|c|c|c|c|c|c|}
\hline \multirow[t]{2}{*}{ Variables } & \multicolumn{3}{|c|}{ Maternal age group Total n(\%) } & \multirow[b]{2}{*}{$\begin{array}{c}\text { OR } \\
(95 \% \mathrm{CI})\end{array}$} & \multirow[b]{2}{*}{$\begin{array}{c}\mathbf{p} \\
\text { value }\end{array}$} \\
\hline & $\begin{array}{l}14-19 \\
\text { years } \\
\text { n(\%) }\end{array}$ & $\begin{array}{l}20-24 \\
\text { years } \\
\text { n(\%) }\end{array}$ & & & \\
\hline $\begin{array}{l}\text { Intrapartum fever } \\
\text { Yes }\end{array}$ & $10(16.7)$ & $4(4)$ & $14(8.8)$ & $4.92(1.51-8.73)$ & 0.009 \\
\hline $\begin{array}{l}\text { Average Apgar } \\
\text { score }\end{array}$ & & & & & \\
\hline 1st minute (SD) & $6.72(2.37)$ & $.55(1.83)$ & $7.24(2.08)$ & $2.07(1.29-3.34)$ & 0.014 \\
\hline 5 th minute (SD) & $7.8(3.21)$ & $.72(2.37)$ & $8.38(2.74)$ & $2.0(0.94-4.27)$ & 0.004 \\
\hline Intrapartumdeath & & & & & \\
\hline Yes & $3(5.0)$ & $2(2.0)$ & $5(5.1)$ & $2.58(0.41-7.58)$ & 0.364 \\
\hline
\end{tabular}

\section{DISCUSSION}

In the present study $26 \%$ of teenagers were married, reflecting the general figure of marital status in this age group in our country as shown in previous studies (Ekanem AD, 2001;) (Enquête Démographique et de Santé et à Indicateurs Multiples(EDS-MICS), 2011) where 14.9\% of adolescents of 15 to 19 years old were married and $35.8 \%$ pregnant adolescents of 14 to 19 years were married respectively. Our results are different from what is known in some low- and middle income countries where early marriages are common in pregnant teenagers (Nair A, 2015)and reach a level of $99.65 \%$ in Egypt. In this study, only $17 \%$ of teenagers attained tertiary level of education. Even when those with a secondary level of education are added, the educational level in the older group was still higher. This is different from results of the most recent Demographic and Health Surveys conducted in 2011 in Cameroon, where the girls of 15 to 19 years old were more literate with $62.7 \%$ being at secondary or tertiary level compared to $54 \%$ of women aged 20 to 24 years old at the same level of education (Nair A, 2015). The difference may be explained by the hospital-based data that might differ from population-based data.

A non-statistically significant trend was observed among teenage mothers and their counterparts in terms of number of antenatal visits, level of health facilities and quality of staff they attended. This trend was similar to that reported in other studies in Egypt (Edessy M, 2014)with $93.6 \%$ of teenagers and $91.7 \%$ of adults attending antenatal visits. The same observation was made in Cameroon (Egbe TO, 2015) with $40.5 \%$ teenagers and $42.2 \%$ adults respectively who attended at least 4 antenatal visits without a significant difference. Other studies gave different trends (Kongnyuy EJ, 2008) in Cameroon and (Iloki LH, 2004) ${ }^{13}$ in Congo Brazzaville with a high prevalence of non-attendance of antenatal visits up to $22.1 \%$ in Congo. Inspite of a good attendance of antenatal visits, we observed a poor compliance to intermittent treatment of malaria with only $64 \%$ teenage mothers being on scheduled treatment compared to $82.8 \%$ of adults ( $p$ value $=0.041$ ). This poor compliance was a mark of inappropriate antenatal care. Furthermore, there was a fivefold tendancy of having fever among teenage mothers during labor. The fever was attributed to malaria. Similar findings were reported by iloki et al. (Iloki LH, 2004)who had 14.1\% of fever among teenage mothers and $7.3 \%$ among adults. The 
poor compliance to scheduled IPT of malaria may explain the occurrence of fever due to malaria among teenage mothers.

In our study there was a two-fold probability of having Apgar score below 7 at first minute in neonates from teenage mothers. Similar results were reported (Iloki LH, 2004). Other studies, (Kemfang Ngowa JD K. J., 2015), (Fouelifack FY, 2014) and (Kumbi S1, 1999)did not find a significant difference in Apgar score as well in the first minute as in the fifth minute. An association exists between poor quality of antenatal care, fever during labor and abnormal Apgar score at birth (Fouelifack FY, 2014) ${ }^{16}$. No post-term, no prolonged or obstructed labor was found to justify this predominance of abnormal Apgar score among neonates in teenage mothers' group.

Teenage pregnancy is still associated with adverse maternal and neonatal outcomes. This is due to poor attendance of antenatal care, high frequency of fever due to malaria and poor Apgar score in neonates. There is a need to implement specific health programs focused on the access of teenagers to reproductive health programs and pregnancy care.

\section{Références}

Chandra-Mouli V, A. V. ( 2013). WHO Guidelines on Preventing Early Pregnancy and Poor Reproductive Outcomes among Adolescents in Developing Countries. . J Adolesc Health, 52, 517-22.

Edessy M, G. M. (2014). Teenage pregnancy and fetal outcome. AJRC, 2(10), 169-175.

Egbe TO, O. A.-E. (2015). Prevalence and outcome of teenage hospital births at the buea health district, South West Region, Cameroon. Reproductive Health, 12, 118.
Ekanem AD, E. S. (2001;). Socio-economic background of pregnant teenagers in Calabar, Nigeria. Int $J$ Soc Sci Public Policy, 4, 235-42.

(2011). Enquête Démographique et de Santé et à Indicateurs Multiples(EDS-MICS). Yaoundé.

Fouelifack FY, T. T. (2014). Outcome of deliveries among adolescent girls at the Yaoundé central hospital. BMC Pregnancy Childbirth, 14, 102.

Iloki LH, K. R. (2004). Pregnancy and childbirth in adolescents in Congo about 276 cases CHU Brazzaville. J Gynecol Obstet Biol Reprod, 33(1), 3742.

Kemfang Ngowa JD, K. J. ( 2015). C. Obstetrical and Perinatal Outcomes of Adolescent Pregnancies in Cameroon: A Retrospective Cohort Study at the Yaoundé General Hospital. OJOG, 5, 88-93.

Kemfang Ngowa JD, K. J. (2015). Obstetrical and Perinatal Outcomes of Adolescent Pregnancies in Cameroon: A Retrospective Cohort Study at the Yaoundé General Hospital. OJOG, 5, 88-93.

Kongnyuy EJ, N. P. (2008). Adverse perinatal outcomes of adolescent pregnancies in Cameroon. Matern Child Health J, 12, 149-54.

Kumbi S1, I. A. (1999). Obstetric outcome of teenage pregnancy in northwestern Ethiopia. East Afr Med J, 76(3), 138-40.

Nair A, D. S. (2015). Obstetric outcome of teenage pregnancy in comparison with pregnant women of 2029 years: a retrospective study. Int $J$ Reprod Contracept Obstet Gynecol, 4(5), 1319-1323.

Nkwabong E, F. J. (2009). Adolescent pregnancies and deliveries: Problems encountered. Tropical Doctor, 39, 9-11.

Tebeu PM, K. J. (2011). Geographic Distribution of Childbirth among Adolescents in Cameroon from 2003 to 2005. Obstetrics and Gynecology International, 2010, 6 pages . doi:10.1155/2010/805165

\section{How to cite this article:}

Belinga E et al (2017) ' Teenage Pregnancy Outcomes In Teaching Hospitals In Yaoundé', International Journal of Current Advanced Research, 06(04), pp. 3206-3208.

DOI: http://dx.doi.org/10.24327/ijcar.2017.3208.0226 